\title{
CONTENT OF PHENOLIC COMPOUNDS IN VARIOUS SEA BUCKTHORN PARTS
}

\author{
Elga Šnē", Dalija Seglina*a Ruta Galoburda**, and Inta Krasnova* \\ * Latvia State Institute of Fruit Growing, Graudu iela 1, Dobele, LV-3701, LATVIA; \\ elga.sne@gmail.com \\ ** Faculty of Food Technology, Latvia University of Agriculture, Lielā iela 2, Jelgava, LV-3001, LATVIA
}

Contributed by Dalija Seglina

\begin{abstract}
All parts of the sea buckthorn (Hippophae rhamnoides L.) plant are considered to contain large amounts of compounds that are believed to have beneficial health effects. Till now, different parts of sea buckthorn plant have been used for the treatment of diseases in traditional medicine in various countries. Nevertheless, sea buckthorn parts would be a good raw material not only for medicinal properties but also for food products with functional properties; therefore, the aim of the research was to determine the concentration of different phenolic compounds and antioxidant activity in various sea buckthorn parts. The study was conducted on parts of female and male sea buckthorn bushes. Phenolic compounds (total phenols, total flavonoids and condensed tannins) and antioxidative activity (ferric reducing antioxidant power (FRAP) free radical scavenging activity (using 2.2-diphenyl-1-picrylhydrazyl, DPPH)) in ethanolic extracts of leaves, shoots, flowers, and berries were determined using various spectrophotometric methods. The study showed that concentration of phenolic compounds differed among parts of sea buckthorn plant and among gender. Leaves of female plants proved to be the most valuable, as they contained the highest total phenol concentration $(165.76 \mathrm{mg} / \mathrm{g})$ and antioxidant activity $(220.97 \mathrm{mg} / \mathrm{g}$ for FRAP and 43.76 $\mathrm{mg} / \mathrm{g}$ for DPPH), while lowest values were found in young shoots of male plants $(84.94 \mathrm{mg} / \mathrm{g}$, $94.24 \mathrm{mg} / \mathrm{g}$ and $24.63 \mathrm{mg} / \mathrm{g}$, respectively). The significant differences in chemical composition and biological activity of sea buckthorn leaves, shoots, berries, and buds indicate a need for detailed studies of their extracts, specific fractions and compounds during a whole vegetative season.
\end{abstract}

Key words: leaves, shoots, berries, flowers, gender, flavonoids, phenols, tannins, antioxidant activity.

\section{INTRODUCTION}

Sea buckthorn (Hippophae rhamnoides L.) is a thorny shrub, native to Europe and Asia (Saggu et al., 2007). Berries of sea buckthorn have been much studied and their chemical composition and positive qualities are well documented. This has led to the outcome that mainly berries of this particular plant are used as a raw material for food processing (Guliyev et al., 2004) in jams, beverages, candies, etc. Nevertheless all parts of sea buckthorn plant have been considered valuable, as they contain large amounts of different bioactive substances, including a wide range of polyphenols, tocopherols, carotenoids, fatty acids, sterols, vitamins, minerals, etc. (Saggu et al., 2007; Jain et al., 2008; Kumar et al., 2011). Till now, different parts of sea buckthorn (other than berries) have been used in traditional medicine for the treatment of diseases, such as flu, colitis and enterocolitis, also cardiovascular illnesses, mucosal injuries, dermatological, and digestion disorders (Guliyev et al., 2004; Kumar et al., 2011). These therapeutic effects mostly are related to the high amount of compounds possessing antioxidant activity (Saggu et al., 2007; Kumar et al., 2011). This is in accordance with many reports that have reported a positive correlation between daily intake of fruit, vegetables and other products of plant origin and health improvement (Michel et al., 2012).

Therefore, in recent years there is a growing interest and demand for natural substances, mainly phenolics derived from plants, which exhibit this property and could be used as food components or pharmaceuticals (Uttara et al., 2009; Wannes et al., 2010). Aromatic and medicinal plants are a good source of natural antioxidants, because of large amounts of secondary metabolites, such as polyphenols and essential oils (Wannes et al., 2010), which are produced by plants for normal growth and development (Kondakova et al., 2009) to defend against plant pathogens, UV stress or to attract pollinators (Michel et al., 2012). 
However, only some studies have conducted analyses of phenolic compounds and their activity in sea buckthorn leaves and shoots, and no information can be found regarding concentrations in flowers, green berries, and regarding effects of gender and harvest time on these qualities. Therefore, the aim of the research was to determine the concentrations of various phenolic compounds and antioxidant activity in various sea buckthorn parts.

\section{MATERIALS AND METHODS}

Plant material. Sea buckthorn material was collected in 2011, in Dobele, Latvia. Flowers of male plants were harvested at time of pollination (late April), while leaves, shoots, unripe berries of female plants and leaves, shoots of male plants after 7 weeks of blossoming (middle of June). Equal amounts $(100 \pm 0.1 \mathrm{~g})$ of every sea buckthorn part were dried by liophilisation (FreeZone, Labconco, USA) at $-50 \pm 2{ }^{\circ} \mathrm{C}$ under $0.056 \mathrm{mBar}$ pressure for $16 \mathrm{~h}$.

Extraction procedure. Dried parts of sea buckthorn were pulverised in a laboratory mill (Knifetec 1095, Foss, Sweden). Extraction was performed in three steps. First, $40 \mathrm{ml}$ $80 \%$ ethanol was added to $1 \mathrm{~g}$ of the sample, shaken for $1 \mathrm{~min}$, placed in the ultrasonic bath (Sonorex RK $510 \mathrm{H}$, Bandelin electronic GmbH \& Co. KG, Germany) for $15 \mathrm{~min}$ at $50{ }^{\circ} \mathrm{C}$ and centrifuged (Eppendorf Centrifuge 5804R, Eppendorf AG, Germany) at $10000 \mathrm{~g}$ for $10 \mathrm{~min}$ at $4{ }^{\circ} \mathrm{C}$. Clear supernatant was separated from sediments and placed in an $100 \mathrm{ml}$ flask. The second step was performed by taking the sediments, adding $30 \mathrm{ml} 80 \%$ ethanol and repeating the above described procedure. Thirdly, when $20 \mathrm{ml} 80 \%$ ethanol was added to sediments obtained from the second extraction step. When all of the supernatant was collected, the flask was filled to $100 \mathrm{ml}$, mixed well and centrifuged $\left(10000 \mathrm{~g}, 10 \mathrm{~min}\right.$ at $\left.4{ }^{\mathrm{O}} \mathrm{C}\right)$.

The concentration of obtained ethanolic extracts was 0.01 $\mathrm{g} / \mathrm{ml}$, and due to high concentration of bioactive substances, prior to analyses it was diluted 100 times for total phenol assay, 10 or 25 times for total flavonoid analyses, 30 times for ferric reducing antioxidant power assay, 10 times for free radical scavenging activity and two times for condensed tannin analyses.

\section{Analyses of phenolic compounds}

Total phenol cocentration. The total phenol concentration was determined according to Singleton et al. (1999). FolinCiocalteu reagent (FCR) was prepared from Folin-Ciocalteu stock solution $(10 \mathrm{ml})$ and water $(90 \mathrm{ml})$. The sea buckthorn extract $(1 \mathrm{ml})$ was added to FCR $(5 \mathrm{ml})$ and $\mathrm{Na}_{2} \mathrm{CO}_{3}$ solution $(4 \mathrm{ml})$, mixed and kept for $1 \mathrm{~h}$ in the dark. The absorption was measured at $765 \mathrm{~nm}$ using a spectrophotometer (UV - 1650 PC, Shimadzu, Japan). Results were expressed as mg gallic acid equivalents per $1 \mathrm{~g}$ of dry matter (mg GAE/g DM).

Total flavonoid concentration. Total flavonoid concentration was determined using a spectrophotometric method previously described by Kumar et al. (2011) and Upadhyay et al. (2010). The extract $(1 \mathrm{ml})$ was mixed with water $(2 \mathrm{ml}), 5 \% \mathrm{NaNO}_{2}(0.15 \mathrm{ml})$ and left to react for 6 minutes. Then $10 \% \mathrm{AlCl}_{3}(0.15 \mathrm{ml})$ solution was added, mixed and allowed to react for another 6 minutes Then $4 \% \mathrm{NaOH}$ $(2.0 \mathrm{ml})$ was added to the mixture, shaken and left for 15 minutes The absorption was read at $510 \mathrm{~nm}$. Results were expressed as $\mathrm{mg}$ rutin equivalents per $1 \mathrm{~g}$ of dry matter (mg RUE/g DM).

Condensed tannin concentration. Condensed tannin concentration was determined by a method described by Michel et al. (2012). Sea buckthorn part extract $(0.2 \mathrm{ml})$ was added to $4 \%$ vanillin--ethanolic solution $(2.4 \mathrm{ml})$ and concentrated $\mathrm{HCl}(1.2 \mathrm{ml})$ and allowed to stand for $15 \mathrm{~min}$. The absorption was detected at $500 \mathrm{~nm}$ by a spectrophotometer. Results were expressed as $\mathrm{mg}$ catechin equivalents per $1 \mathrm{~g}$ of dry matter (mg CE/g DM).

\section{Antioxidant activity}

DPPH free radical scavenging assay. The free radical scavenging activity was determined according to Brand-Williams et al. (1995) using 2.2-diphenyl-1-picrylhydrazyl (DPPH) reagent prepared by mixing with methanol to reach absorption about 0.9 at wavelength of $515 \mathrm{~nm}$. The extract $(0.131 \mathrm{ml})$ was mixed with DPPH solution $(2.9 \mathrm{ml})$ and left to stand for $30 \mathrm{~min}$ in a dark place. The absorption of samples was read at $515 \mathrm{~nm}$ using a spectrophotometer. Results were expressed in $\mathrm{mg}$ Trolox equivalents per $1 \mathrm{~g}$ of dry matter (mg TE/g DM).

Ferric reducing antioxidant power assay. Reducing antioxidant power evaluation was carried out by a spectrophotometric method described by Benzie and Strain (1996) and Kumar et al. (2011). Before analysis, fresh ferric reducing antioxidant power (FRAP) reagent was prepared by mixing $300 \mathrm{mM}$ acetate buffer ( $\mathrm{pH}$ 3.6), $10 \mathrm{mM}$ 2,4,6- Tripyridyls-Triazine made in $40 \mathrm{mM} \mathrm{HCl}$ and $20 \mathrm{mM} \mathrm{FeCl} \cdot 6 \mathrm{H}_{2} \mathrm{O}$ in the ratio of $10: 1: 1(\mathrm{v} / \mathrm{v} / \mathrm{v})$, respectively, and then warmed at $37{ }^{\circ} \mathrm{C}$ in a water bath. Each extract $(0.210 \mathrm{ml})$ was added to FRAP reagent $(3.8 \mathrm{ml})$ and allowed to stand for $10 \mathrm{~min}$ in the dark. The absorption was detected at wavelength $593 \mathrm{~nm}$. Results were expressed in mg Trolox equivalents per $1 \mathrm{~g}$ of dry matter (mg TE/g DM).

Statistical analysis. Data were analysed using SPSS Statistics 17.0 software. The results were expressed as means \pm standard deviations for at least three experimental measurements. One-way analysis of variance (ANOVA), Duncan multiple range test and Pearson correlation tests were used. Significance was set at $P \sim 0.05$. The Pearson correlation test was performed to determine relationships between chemical parameters.

\section{RESULTS}

There were significant differences $(P<0.05)$ in the concentrations of total phenols, total flavonoids and condensed tannins among parts of sea buckthorn plant (Table 1). 
PHENOL CONTENT IN VARIOUS SEA BUCKTHORN PARTS

\begin{tabular}{c|l|c|c|c}
\hline $\begin{array}{c}\text { Plant } \\
\text { gender }\end{array}$ & Part & $\begin{array}{c}\text { Total phenol } \\
\text { concentration, } \\
\text { mg GAE/g DM }\end{array}$ & $\begin{array}{c}\text { Total flavonoid } \\
\text { concentration, } \\
\text { mg RUE/g DM }\end{array}$ & $\begin{array}{c}\text { Condensed tan- } \\
\text { nin concentra- } \\
\text { tion, } \\
\text { mg RUE/g DM }\end{array}$ \\
\hline Female & Leaves & $165.76 \pm 2.52^{\mathrm{a}}$ & $47.76 \pm 0.43^{\mathrm{c}}$ & $1.32 \pm 0.28^{\mathrm{e}}$ \\
& Shoots & $119.63 \pm 3.67^{\mathrm{c}}$ & $79.57 \pm 0.75^{\mathrm{b}}$ & $22.47 \pm 0.12^{\mathrm{b}}$ \\
Male & Leaves & $123.78 \pm 2.53^{\mathrm{b}}$ & $36.47 \pm 0.27^{\mathrm{e}}$ & $1.03 \pm 0.16^{\mathrm{e}}$ \\
& Shoots & $84.94 \pm 0.91^{\mathrm{e}}$ & $47.01 \pm 1.69^{\mathrm{c}}$ & $11.00 \pm 0.52^{\mathrm{d}}$ \\
& Flowers & $120.16 \pm 0.92^{\mathrm{c}}$ & $81.72 \pm 0.76^{\mathrm{a}}$ & $18.94 \pm 0.73^{\mathrm{c}}$
\end{tabular}

Different letters in a column show significant differences between samples within each analysed parameter at $P \sim 0.05$. Results are expressed as mean \pm standard deviation $(n=4)$. GAE, gallic acid equivalent; RUE, rutin equivalent; CAE, catechin equivalent; DM, dry matter.

The leaves of female and male plants were the best sources of total phenols $(165.76 \mathrm{mg} / \mathrm{g}$ DW and $123.78 \mathrm{mg} / \mathrm{g} \mathrm{DW}$, respectively). The concentration of total flavonoids had the highest level in male flowers $(81.72 \mathrm{mg} / \mathrm{g} \mathrm{DW})$ and the lowest in male leaves $(36.47 \mathrm{mg} / \mathrm{g} \mathrm{DW})$. The shoots and green berries of female sea buckthorn plant contained the highest concentrations of condensed tannins, reaching 22.47 and $23.29 \mathrm{mg} / \mathrm{g}$ DW which was about 20 times higher than in leaves of both genders.

Similar to phenolic compounds, also antioxidant activity significantly differed ( $\mathrm{P} \sim 0.05$ ) between sea buckthorn leaves, shoots, green berries, and flowers. The activity de- termined by the FRAP method (Fig. 1) showed higher values than those by DPPH radical assay (Fig. 2).

The highest antioxidant activity by both methods was observed in leaves of female plants $(220.97 \mathrm{mg} / \mathrm{g}$ DW for FRAP and $43.76 \mathrm{mg} / \mathrm{g}$ DW for DPPH assay), followed by male leaves, female and male shoots.

Pearson correlation coefficients were strong and significant between total phenol and FRAP $(r=0.945)$, and between total phenols and DPPH $(r=0.883)$.

\section{DISCUSSION}

As sea buckthorn leaves and shoots are considered to have a great potential in food processing due to biologically active substances (Shunguang et al., 2003), and especially if collected in summer (as for herbal medicine) when shoots are still green, tender and non-woody. Together with the leaves and shoots, also small green berries were picked. Male flowers were harvested in the middle of spring, because at that time they are rich in pollen, which is thought to contain high amount of bioactive substances.

Although all parts of sea buckthorn plant are considered to contain high levels of hydrophilic (polyphenols, chlorophyll, vitamin C) and lipophilic (carotenoids, tocopherols, vitamin E) compounds (Jain et al., 2008; Saggu and Kumar, 2008; Kumar et al., 2011), only leaves have gained great interest during the last decades.
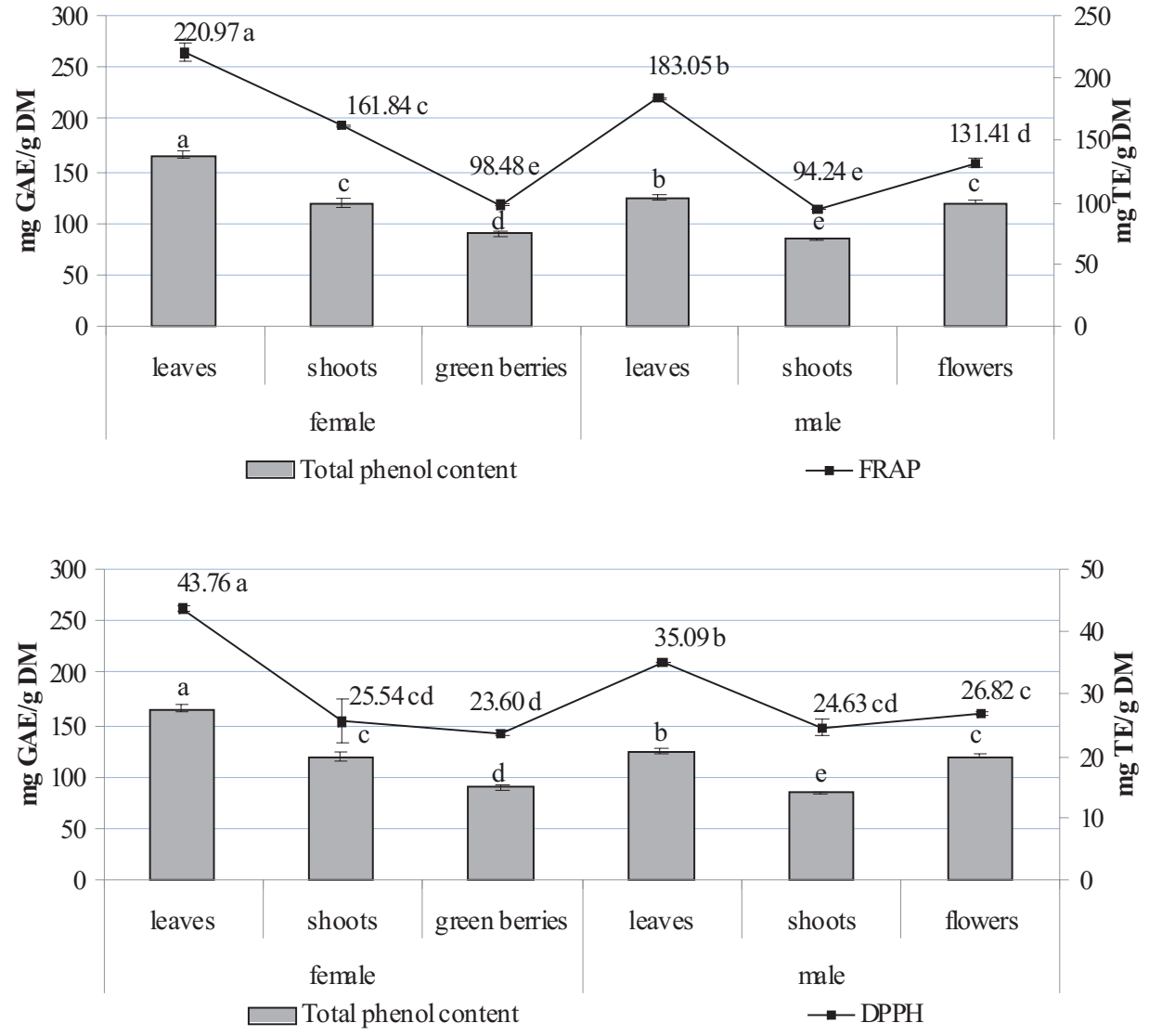

Fig. 1. Ferric reducing antioxidant power (FRAP) and total phenol concentration of sea buckthorn parts. Different letters show significant differences between samples within each analysed parameter at $P \sim 0.05$. Results are expressed as mean \pm standard deviation $(n=4)$. TE, trolox equivalent; GAE, gallic acid equivalent; DM, dry matter. 
In our study, the highest values for total phenol, total flavonoid and condensed tannin concentration were observed in leaves of female plants - $165.76 \mathrm{mg} / \mathrm{g}, 47.76 \mathrm{mg} / \mathrm{g}$ and $1.32 \mathrm{mg} / \mathrm{g}$, respectively. These values are lower than those reported by Upadhyay et al. (2010) for sea buckthorn leaf samples collected in the North-West Himalayas: $56.28 \mathrm{mg} / \mathrm{g}$ total phenols and only $20.76 \mathrm{mg} / \mathrm{g}$ total flavonoids. However, the values in our study were lower than in leaves collected from west Pamirs where flavonoid content varied from 31 to $123.8 \mathrm{mg} / \mathrm{g}$ (Singh, 2006). Michel et al. (2012) in their research found that leaves extracted by ethanol (as in our study) contain $65 \mathrm{mg} / \mathrm{g}$ total phenols and even $13 \mathrm{mg} / \mathrm{g}$ condensed tannins, but the authors used different extraction methods, solvents, and solvent-to-sample ratios, and even small differences can significantly affect the final value. In contrat to the study by Upadhyay et al. (2010), where autumn leaves were studied, we used leaves collected in the beginning of summer. Therefore, seasonal variation should be taken into consideration together with plant age, genetic, agronomic and storage variations. According to Kondakova et al. (2009), fruits of berry plants grown in a colder climate and under a shorter vegetation period have higher levels of phenolic compounds. These differences, governed by geographical region, probably also occur for other plant parts.

Phenolic compounds (flavonoids, phenolic acids, and tannins) are considered to be the major plant compounds possessing antioxidant activity (Upadhyay et al., 2010). Therefore, for better characterisation of sea buckthorn leaves, shoots, berries and flowers, two commonly applied antioxidant activity testing methods were used: ferric reducing antioxidant power and free radical scavenging activity (DPPH). The findings in the current study show that sea buckthorn leaves of both gender shrubs contained the highest amount of total phenols and also possessed the highest antioxidant activity. This was also indicated by Pearson correlation analysis, by a strong and significant relationships between total phenol concentration and FRAP/ DPPH activity in all tested sea buckthorn samples.

The study showed that different parts of sea buckhorn are rich in phenolic compounds and exhibit antioxidant activity, and that the most valuable part with regard to total phenol content and antioxidant activity is leaves from female tree, and the less valuable - shoots from male trees. There are differences in chemical composition and activity of various sea buckthorn parts, and more detailed investigation of their extracts, specific fractions and compounds and their activity during the whole vegetative season is needed.

\section{ACKNOWLEDGEMENTS}

The research was conducted and publication prepared within the framework of the ERAF project "Use of sea buckthorn vegetative parts for development of food products with high antioxidant activity" (2010/ 0246/ 2DP2.1.1.0/ 10/ APIA/ VIAA/ 159).

\section{REFERENCES}

Benzie, I. F, Strain, J. J. (1996). The ferric reducing ability of plasma (FRAP) as a measure of Antioxidant Power: The FRAP assay. Anal. Biochem., 239, $70-76$.

Brand-Williams, W., Cuvelier, M. E., Berset, C. (1995). Use of a free radical method to evaluate antioxidant activity. Lebensmittel-Wiss. Technol./Food Sci. Technol., 28, 25-30.

Guliyev, V. B., Gul, M., Yildirim, A. (2004). Hippophae rhamnoides L.: Chromatographic methods to determine chemical composition, use in traditional medicine and pharmacological effects. J. Chromatogr. B, 812, 291-307.

Jain, M., Ganju, L., Katiyal, A., Padwad, K. P., Mishra, K. P., Chanda, S., Karan, D., Yogendra, K. M. S., Sawhney, R. C. (2008). Effect of Hippophae rhamnoides leaf extract against Dengue virus infection in human blood-derived macrophages. Phytomedicine, 15, 793-799.

Jeong, H. J., Lee, J. W., Kim, K. S., Kim, J. S., Han, S. N., Yu, C. Y., Lee, K. J, Kwon, S. Y., Kim, J. M. (2010). Antioxidant and antimicrobial activities of extracts from a medicinal plant, sea buckthorn. J. Korean Soc. Appl. Biol. Chem., 53 (1), 33-38.

Kondakova, V., Tsvetkov, I., Batchvarova, R., Badjakov, I., Dzhambazova, T., Slavov, S. (2009). Phenol compound - qualitative index in small fruits. Biotechnology Biotechnol. Equip., 23, 1444-1448.

Kumar, Y. M. S., Dutta, R., Prasad, D., Misra, K. (2011). Subcritical water extraction of antioxidant compounds from sea buckthorn (Hippophae rhamnoides) leaves for the comparative evaluation of antioxidant activity. Food Chem., 127, 1309-1316.

Moure, A., Cruz, J. M., Franco, D., Dominguez, J. M., Sineiro, J., Dominguez, H., Nunez, M. J., Parajo, J. C. (2001). Natural antioxidants from residual sources. Food Chem., 72, 145-171.

Michel, T., Destandau, E., Le Floch, G., Lucchesi, M. E., Elfakir, C. (2012). Antimicrobial, antioxidant and phytochemical investigations of sea buckthorn (Hippophae rhamnoides L.) leaf, stem, root and seed. Food Chem., 131, 754-760.

Saggu, S., Divekar, H. M., Gupta, V., Sawhney, R. C., Banerjee, P. K., Kumar, R. (2007). Adaptogenic and safety evaluation of seabuckthorn (Hippophae rhamnoides) leaf extract: A dose dependent study. Food Chem. Toxicol., 45, 609-617.

Saggu, S., Kumar, R. (2008). Effect of seabuckthorn leaf extracts on circulating energy fuels, lipid peroxidation and antioxidant parameters in rats during exposure to cold, hypoxia and restraint $(\mathrm{C}-\mathrm{H}-\mathrm{R})$ stress and post stress recovery. Phytomedicine, 15 (6-7), 437-446.

Shunguang, L., Zhengping, J., Xiufeng W., Keqin W., Dengming L. (2003). Sea buckthorn breeding for the purpose of leaves utilization. In: Proceedings of the $1^{\text {st }}$ Congress of the International Seabuckthorn Association, 14-18 September 2003 (pp. 36-46). Berlin.

Singh, V. (2006). Free radicals, diseases, anti-oxidants and anti-oxidant properties of seabuckthorn (Hippophae rhamnoides L.). In: Singh, V. (Ed.). Seabuckthorn (Hippophae L.). A Multipurpose Wonder Plant. Vol. II: Biochemistry and Pharmocology (pp. 3-69). Delhi: Daya Publishing House.

Singleton, V. L., Orthofer, R., Lamuela-Raventos, R. M. (1999). Analysis of total phenols and other oxidation substrates and antioxidants by means of Folin-Ciocalteau reagent. Meth. Enzymol., 299, 152-178.

Upadhyay, N. K., Kumar, M. S. Y., Gupta, A. (2010). Antioxidant, cytoprotective and antibacterial effects of Sea buckthorn (Hippophae rhamnoides L.) leaves. Food Chem. Toxicol., 48, 3443-3448.

Uttara, B., Singh, A. V., Zamboni, P., Mahajan, R. T (2009). Oxidative stress and neurodegenerative diseases: A review of upstream and downstream antioxidant therapeutic options. Curr. Neuropharmacol., 7 (1), 65-74.

Wannes, W. A, Mhamdi, B, Sriti, J, Jemia, M. B., Ouchikh, O., Hamdaoui, G., Kchouk, M. E., Marzouk, B. (2010). Antioxidant activities of the essential oils and methanol extracts from myrtle (Myrtus communis var. italica L.) leaf, stem and flower. Food Chem. Toxicol., 48 (5), 1362-1370. 


\section{FENOLSAVIENOJUMU SATURS DAŽĀDĀS SMILTSĒRKŠĶU AUGA DAḶĀS}

Rakstā aplūkots fenolsavienojumu saturs dažādās smiltsērkšķu auga daḷās un to antioksidatīiā aktivitāte. Kā pētījuma objekts izvēlētas sievišķo un vīrišķo augu lapas, jaunie dzinumi, zal̦ās ogas, kas ievāktas jūnija vidū, un ziedi, kas ievākti aprīla beigās. Paraugiem analizēts kopējo fenolu, kopējo flavonoīdu un kondensēto tanīnu saturs, kā arī antioksidatīvā aktivitāte ar FRAP (ferric reducing antioxidant power) un DPPH (2.2-diphenyl-1-picrylhydrazyl) metodi. Vērtīgākā auga dą̣a izrādījās sievišķā auga lapas, kurām konstatēts augstākais kopējo fenolu saturs un antioksidatīvā aktivitāte, lietojot abas metodes, savukārt vismazākie minētie rādītāji bija jaunajiem dzinumiem no vīrišķā auga. Rezultāti norāda uz būtiskām atšḳirībām smiltsērkšḳu auga dạu kịmiskajā sastāvā un bioloǵiskajā aktivitātēe, tādēḷ nepieciešami padziḷināti pētījumi par ekstraktiem, to frakcijām vai atsevišḳiem savienojumiem un to izmaiṇām visā veğetācijas sezonā. 